BMJ Open

Sport \&

Exercise

Medicine

\title{
Severity and pattern of injuries caused by the traditional Swiss team sport 'Hornussen': first retrospective study at a level I trauma centre in Switzerland
}

\author{
Volkmar Waterkamp, ${ }^{1}$ Meret Ricklin, ${ }^{2}$ Benoît Schaller, ${ }^{3}$ Konstantinos Katsoulis, ${ }^{3}$ \\ Aristomenis Exadaktylos ${ }^{2}$
}

To cite: Waterkamp V, Ricklin M, Schaller B, et al. Severity and pattern of injuries caused by the traditional Swiss team sport 'Hornussen': first retrospective study at a level I trauma centre in Switzerland. BMJ Open Sport Exerc Med 2016;2: 000122 .

doi:10.1136/bmjsem-2016000122

- Prepublication history for this paper is available online. To view these files please visit the journal online (http://dx.doi.org/10.1136/ bmjsem-2016-000122).

Accepted 19 July 2016

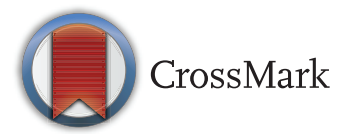

${ }^{1}$ Department of Anaesthesiology, Siloah Hospital, Gümligen, Switzerland

${ }^{2}$ Department of Emergency Medicine, University Hospital, Bern, Switzerland

${ }^{3}$ Department of Cranio-

Maxillofacial Surgery,

University Hospital, Bern, Switzerland

Correspondence to Dr Volkmar Waterkamp; volkmar.waterkamp@siloah.ch

\section{ABSTRACT}

Background: This article addresses typical injury patterns related to the traditional Swiss team sport of Hornussen. A small plastic disk is struck with a special elastic racket and then intercepted in the field. Severe injuries have occasionally been reported. We present a systematic review of all cases of Hornussen injuries treated in the University Hospital of Bern from 2000 to 2014.

Methods: To assess the frequency, type and outcome of Hornussen injuries, we performed a database search of all inpatient and outpatient cases related to Hornussen and that were admitted to and/or treated in Bern University Hospital from 2000 to 2014.

Results: A total of 28 such patients could be identified. Apart from 1 woman injured as a bystander and treated as an outpatient, all patients were male and active players. Typical injury patterns comprised midfacial fractures and severe ocular traumata, very often in combination. Almost all of these patients had to be hospitalised due to the severity of the trauma suffered and underwent surgery. 1 patient had to be admitted to the intensive care unit prior to the operation.

Conclusions: Eye and face injuries caused by Hornussen can be devastating. This resembles the potential risk of other bat-and-ball sports, such as cricket and baseball. Apart from the economic loss due to treatment costs and sick leave, these injuries can be disabling for life. It should therefore be mandatory for all players to wear protective gear, as is already the case for Hornussen players born in 1984 or later.

\section{INTRODUCTION}

Hornussen is an indigenous national team sport originating in the Central Swiss Plateau. A small plastic disk (the 'Nouss' or 'Hornuss') is placed on a launching ramp (the 'Bock') and struck with a small block made of compressed hardwood (the 'Träf'), which is fixed at the end of a special elastic racket (the 'Stecken') by a member of one team (figure 1) and then intercepted

\section{What are the new findings?}

- This is the first in-depth assessment of characteristic Hornussen sport injury cases admitted to a level I trauma centre in Switzerland.

- Midfacial fractures combined with blunt or perforating ocular traumata were found to be frequent injury patterns.

- Injuries were mostly severe and the majority of patients had to be hospitalised and surgically treated.

- An effective precaution would be helmet protection for all Hornussen players.

('abgetan') in the field ('Ries') with special wooden shields (the 'Schindeln') by members of the other team (figure 2). ${ }^{1-3}$ During the match, both teams play both parts of the game. The team with the better intercepting performance wins the match. If the interception results are identical, the team with the greater total flight distances of the Nouss wins. Thus, in Hornussen, 'defence' is more important than 'attack'.

The exact roots of Hornussen are unknown. It may have emerged from the heathen custom of hitting burning logs from the mountain to the valley to cast out demons $^{4}$ or perhaps from medieval war games. ${ }^{5}$ Hornussen was officially documented for the first time in 1625 , when four men were reprimanded by the consistory of Lauperswil for playing Hornussen during 'catechisation and prayer service'. ${ }^{6}$ Interestingly, the first Hornussen accident was reported as early as 1738 , after a player had been fatally wounded to his carotid artery by a broken Stecken. ${ }^{6} 7$

The rules of the game have progressively evolved since the 17th century. Today Hornussen is performed with standardised and highly developed equipment (eg, high- 
Figure 1 Hornussen player driving the Nouss off the Bock. (Inlay: Träf at the end of the Stecken approaching the Nouss).

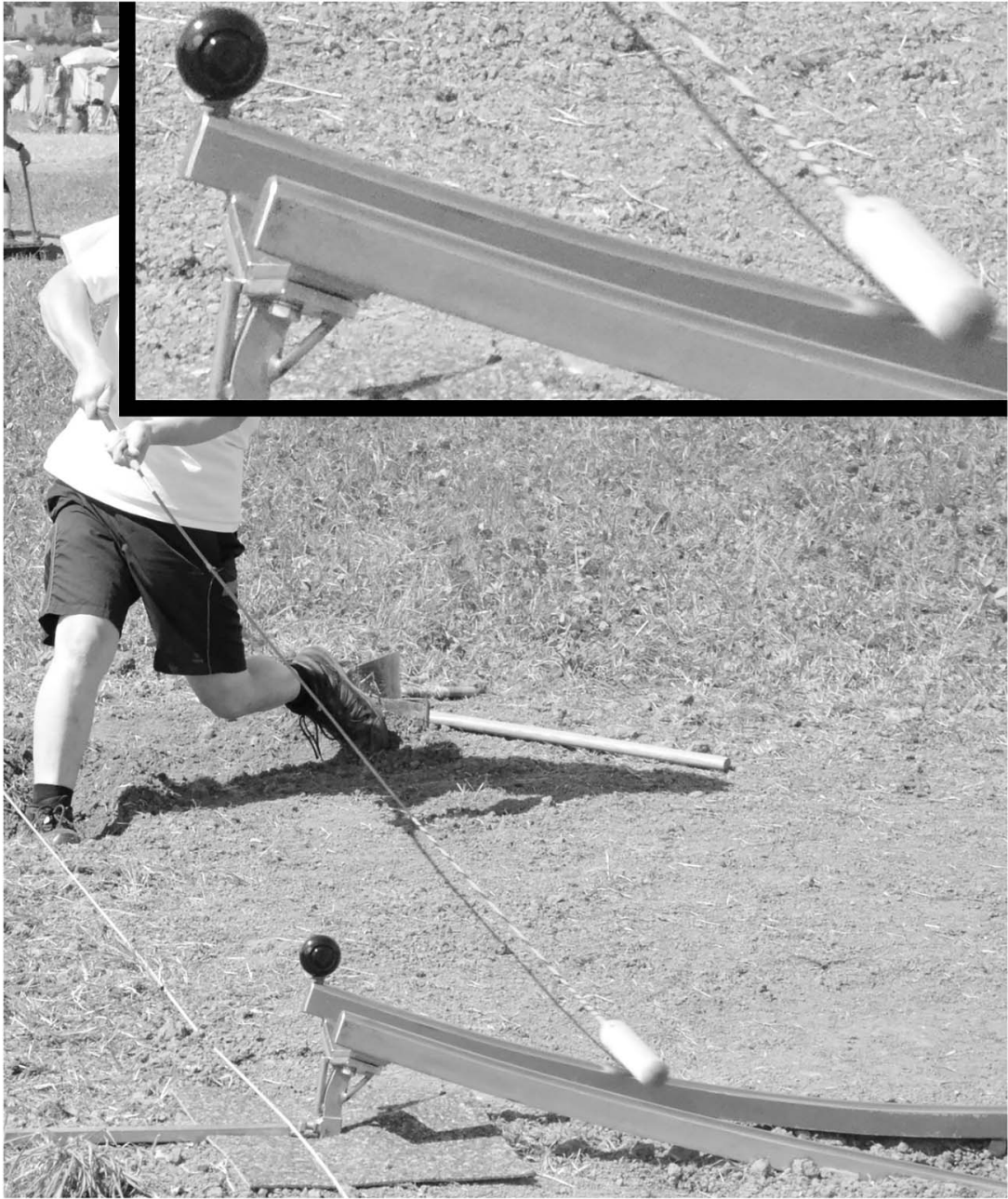

tech Steckens made of carbon fibre), as an organised team sport with championships in different leagues under the aegis of the national Swiss Hornusser Association (Eidgenössischer Hornusserverband) ${ }^{8}$ with currently 7411 licensed members (Eidgenössischer Hornusserverband, personal communication). Up to $80 \%$ of these fall within the scope of our hospital's catchment area (Eidgenössischer Hornusserverband, personal communication). ${ }^{9}$ The number of unorganised casual players is unknown.

The Nouss itself weighs $78 \mathrm{~g}$ and is $62 \times 32 \mathrm{~mm}$. It is placed and fixed on the Bock with a small piece of clay (figure 1). When struck with the Stecken's Träf, the Nouss reaches initial velocities of $80-85 \mathrm{~m} / \mathrm{s}$ (ie, around $300 \mathrm{~km} /$ hour), with an initial energy of about $250 \mathrm{~J}^{5}{ }^{10}$ After a flight of $\sim 300 \mathrm{~m}$, the impact energy of the Nouss is still about $60-70 \mathrm{~J}$, resulting in energy density values between 0.15 and $0.3 \mathrm{~J} / \mathrm{mm}^{2}$ when hitting soft or hard tissue (eg, skin or bones). This is more than sufficient to cause contused lacerations or fractures of thinner bones, for example, those in the midface. ${ }^{511}$

These hazards resemble those in better known bat-and-ball sports like cricket or baseball. However, Hornussen is mostly performed without any protective measures such as helmets. Apart from the aforementioned historic reference of 1738 , severe injuries have been reported in two scientific publications ${ }^{12} 13$ and occasionally in the daily press, ${ }^{14-16}$ especially devastating ocular injuries. These injuries can be avoided by wearing protective equipment, depending on the type of injury.

Bearing this in mind, we retrospectively evaluated the type and severity of the injuries caused by this sport. To the best of our knowledge, there has been no systematic review of Hornussen accidents before. This is therefore the first in-depth study of injuries and injury patterns caused by Hornussen.

\section{METHODS}

\section{Hospital unit and patient population}

The University Department of Emergency Medicine of the Inselspital Bern serves as a level I centre for patients older than 16 years, and commands a catchment area of 1.5 million people. It treats more than 38000 patients each year.

Our study was performed as a retrospective database query of all patients admitted to or initially treated in the Emergency Department from 1 January 2000 to 31 December 2014. The software used was Qualicare ${ }^{17}$ 
Figure 2 Hornussen players intercepting the Nouss (upper left corner) in the Ries with their Schindeln.

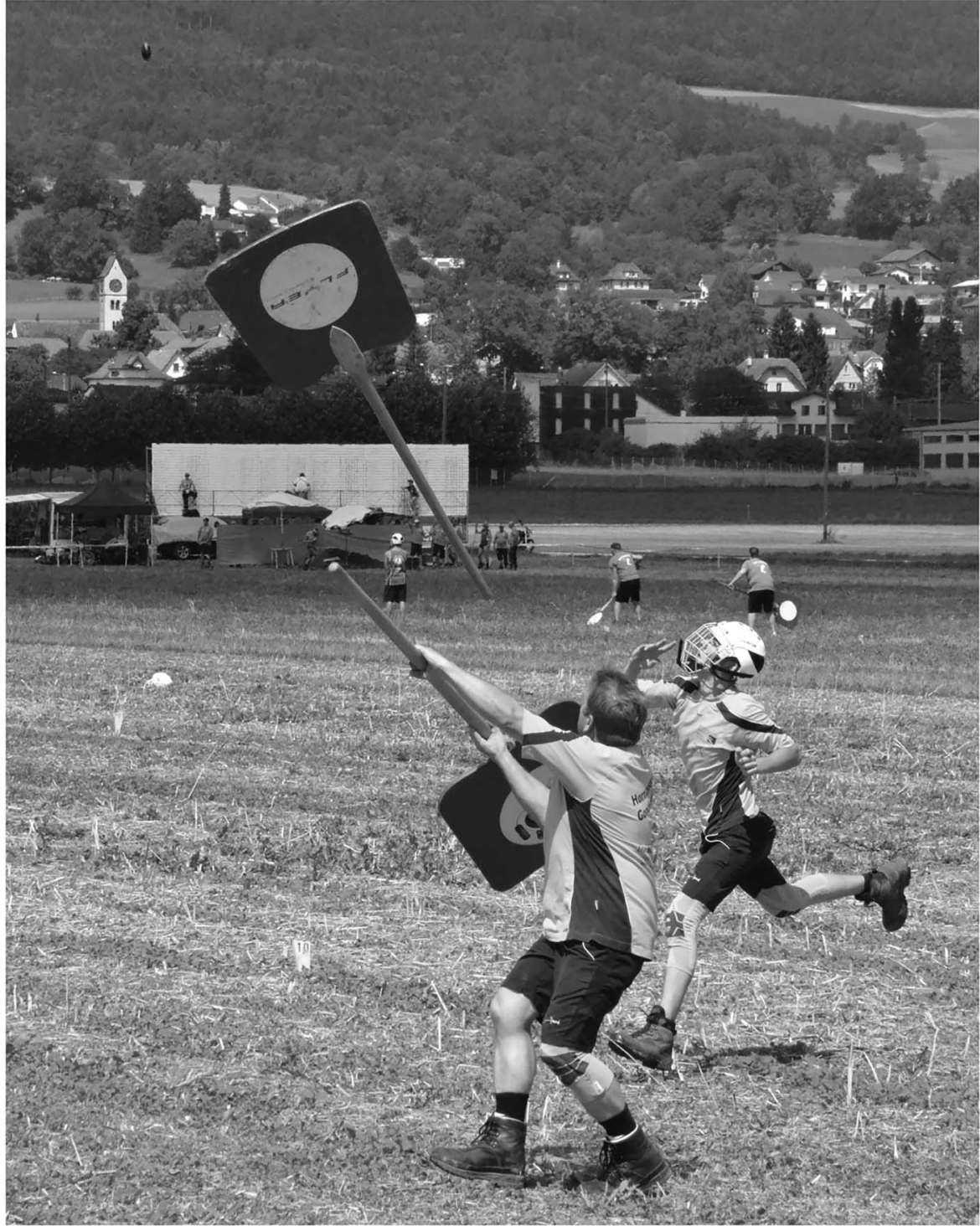

(Qualidoc AG, Trimbach, Switzerland) and E.Care (E.Care BVBA, Turnhout, Belgium). Case files related to Hornussen were identified by corresponding search terms and exported anonymously. Restriction to active players was not intended.

The database entries comprise basic demographic data (eg, age and gender), as well as relevant historical details of medical symptoms or the type of accident (eg, direct or ricocheted hits by a Hornuss or hits by the Stecken). The database also provided the results of clinical consultations and radiological examinations, together with medical and traumatological diagnoses and information on treatment after admission. The short-term outcome was defined by the type of care given to each patient (outpatient, inpatient, intensive care unit (ICU), surgery or no surgery) and recorded as well.

\section{Application of the FISS}

In so far as was retrospectively possible, we also classified the patients by means of the Facial Injury Severity Scale
(FISS; table 1). FISS was introduced in 2006, primarily as a tool for the assessment and management of maxillofacial trauma. ${ }^{18}{ }^{19}$ It was subsequently adopted for research and has become the most frequently cited tool for scoring maxillofacial trauma. ${ }^{20}$ FISS yields a numerical value composed of the sum of individual fractures and/or fracture patterns. It ranges from 0 to over 25 in theory, but the highest FISS reported in the initial publication with 1115 patients was 13 . $^{18}$

Our database entries proved to be complete enough to allow reliable determination of each patient's FISS. The exact extent of facial lacerations was not recorded in all cases, but never came close to a combined length of $10 \mathrm{~cm}$. Consequently, we decided always to assign 0 points for this item, although it remains possible that the FISS of a very few patients was then under-rated by 1 point.

Data were fully anonymised before analysis and therefore, according to local law, no prior consent was necessary. Statistical evaluation was purely descriptive, due to the small sample size. 
Table 1 Facial Injury Severity Scale (FISS)

\begin{tabular}{|c|c|c|}
\hline $\begin{array}{l}\text { Anatomical } \\
\text { region }\end{array}$ & Type of injury & Points \\
\hline \multirow[t]{3}{*}{ Mandible } & Dentoalveolar fracture & 1 \\
\hline & $\begin{array}{l}\text { Each fracture of body/ } \\
\text { ramus/symphysis }\end{array}$ & 2 \\
\hline & $\begin{array}{l}\text { Each fracture of condyle/ } \\
\text { coronoid }\end{array}$ & 1 \\
\hline \multirow[t]{8}{*}{ Midface* $^{*}$} & Dentoalveolar fracture & 1 \\
\hline & Le Fort I fracture $†$ & 2 \\
\hline & Le Fort II fracture & 4 \\
\hline & Le Fort III fracture & 6 \\
\hline & NOE fracture & 3 \\
\hline & ZMC fracture & 1 \\
\hline & Nasal fracture & 1 \\
\hline & $\begin{array}{l}\text { Orbital floor or inferior rim } \\
\text { fracture }\end{array}$ & 1 \\
\hline \multirow[t]{3}{*}{ Upper face } & $\begin{array}{l}\text { Orbital roof or superior rim } \\
\text { fracture }\end{array}$ & 1 \\
\hline & $\begin{array}{l}\text { Displaced frontal sinus/bone } \\
\text { fracture }\end{array}$ & 5 \\
\hline & $\begin{array}{l}\text { Non-displaced frontal sinus/ } \\
\text { bone fracture }\end{array}$ & 1 \\
\hline Facial lacerations & Combined length $>10 \mathrm{~cm}$ & 1 \\
\hline \multicolumn{3}{|c|}{$\begin{array}{l}\text { *Each midfacial fracture is assigned } 1 \text { point, unless it is part of a } \\
\text { complex. } \\
\text { †Unilateral Le Fort fractures are assigned half the number of } \\
\text { points. } \\
\text { NOE, naso-orbital-ethmoid; ZMC, zygomaticomaxillary complex. }\end{array}$} \\
\hline
\end{tabular}

\section{RESULTS}

\section{Sample size}

A total of 39 case files from the period 1 January 2000 to 31 December 2014 were initially identified as being related to Hornussen accidents. After rigorous inspection of each file, 11 patients were excluded from further analysis as they were found not to be specifically related to Hornussen accidents. Typical examples comprised acute cardiological or neurological episodes suffered during Hornussen like coronary ischaemia or stroke, as well as falls or stumbles leading to a torn muscle fibre or a broken ankle.

The remaining 28 case files showed a more or less constant annual rate of 0-4 Hornussen accidents admitted to the University Emergency Department each year (figure 3). There was only one female patient (4\%), who was involved as a bystander; 27 patients $(96 \%)$ were active male players aged between 19 and 71 years (median 40.4 years). Although this female patient did not represent the typical risk group, she was kept for data evaluation as the trauma mechanism was definitely characteristic. It was striking that none of these patients had used any protective gear.

\section{Typical injuries and treatment}

The face and skull $(n=26)$ were the most frequently injured body regions (93\%, figure 4). The remaining patients $(n=2)$ suffered injuries to the upper and lower

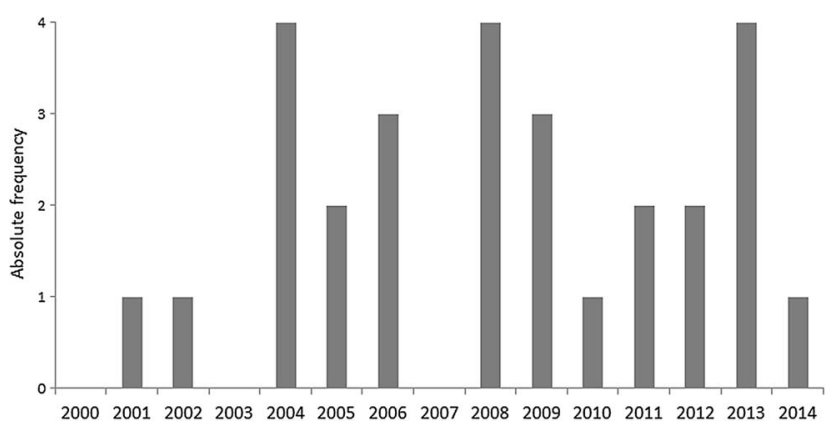

Figure 3 Annual distribution of admissions for Hornussen accidents between 2000 and 2014 .

extremities (7\%). These two patients were treated as outpatients, one after minor surgery under local anaesthesia. Twenty-two $(79 \%)$ of the patients were hit by a flying Nouss, $4(14 \%)$ were injured when striking the Nouss, either by hitting themselves with the Träf or by being hit by parts of a broken Stecken or Nouss. For two patients $(7 \%)$, no clear description of the accident's circumstances was found in the case file.

As the vast majority of 26 patients suffered injuries to the face and skull only, many with complex trauma patterns, we concentrated on the extensive analysis of these cases. The detailed information for each patient can be found in table 2 .

As aforementioned, the impact energy of the Nouss when reaching the Ries is easily above the limit for causing severe damage to soft and hard tissues. Thus, it was no surprise that 20 of 26 patients (77\%) with face/ skull injuries had to be hospitalised due to the severity of the trauma and that all of those patients had to undergo surgery. One patient with subdural haematoma was admitted to the ICU for monitoring prior to operation (figure 5).

Six patients $(23 \%)$ could be treated as outpatients; four underwent minor surgery such as wound cleaning and suture. The median outpatient FISS was only 0.5

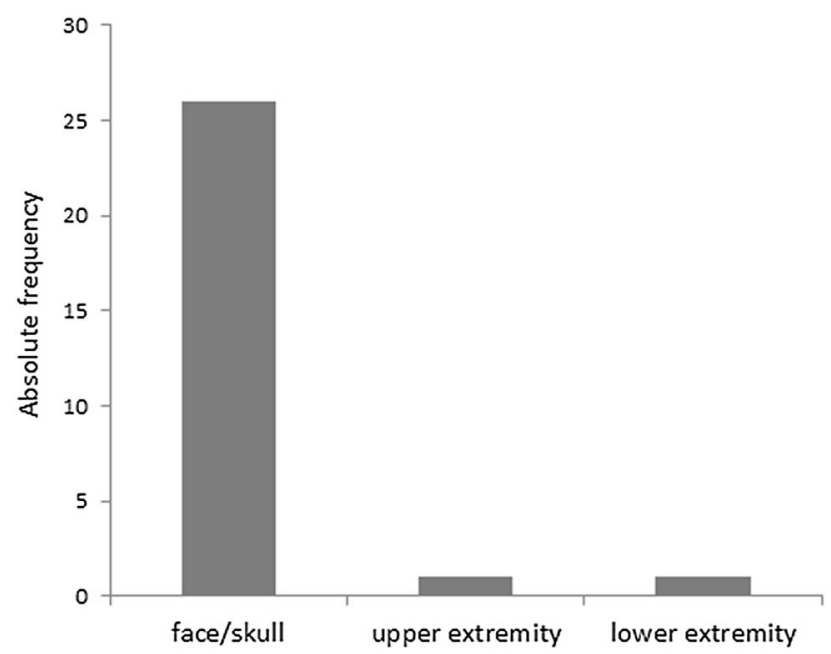

Figure 4 Distribution of injured body regions. 
Table 2 Patients' characteristics

\begin{tabular}{|c|c|c|c|c|c|c|}
\hline $\begin{array}{l}\text { Patient } \\
\text { number }\end{array}$ & Gender & Age & Cause of accident & Diagnoses & FISS & Outcome \\
\hline 1 & M & 31 & $\begin{array}{l}\text { Hit himself with the Träf } \\
\text { while striking }\end{array}$ & $\begin{array}{l}\text { Fracture of the right lateral orbital wall, } \\
\text { contusion of the right eye with contused } \\
\text { laceration of the eyebrow }\end{array}$ & 1 & $\begin{array}{l}\text { Hospital/ } \\
\text { surgery }\end{array}$ \\
\hline 2 & M & 71 & Hit by a Nouss & $\begin{array}{l}\text { Fracture/loss of several teeth, contused } \\
\text { laceration of the upper lip }\end{array}$ & 2 & $\begin{array}{l}\text { Hospital/ } \\
\text { surgery }\end{array}$ \\
\hline 3 & $M$ & 43 & $\begin{array}{l}\text { Nasal trauma at } \\
\text { Hornussen } 6 \text { days } \\
\text { previously }\end{array}$ & $\begin{array}{l}\text { Comminuted fracture of the nasal bone with } \\
\text { intense bleeding }\end{array}$ & 1 & $\begin{array}{l}\text { Hospital/ } \\
\text { surgery }\end{array}$ \\
\hline 4 & $\mathrm{~F}$ & 70 & $\begin{array}{l}\text { Hit by a ricocheted } \\
\text { Nouss as a bystander } \\
2 \text { weeks previously }\end{array}$ & $\begin{array}{l}\text { Bilateral periorbital haematoma, unspecific } \\
\text { vertigo }\end{array}$ & 0 & Home \\
\hline 5 & M & 64 & Direct hit by a Nouss & $\begin{array}{l}\text { Fracture of the left orbital roof, floor and } \\
\text { ethmoid, ocular contusion, contused laceration } \\
\text { of both eyelids }\end{array}$ & 4 & $\begin{array}{l}\text { Hospital/ } \\
\text { surgery }\end{array}$ \\
\hline 6 & M & 62 & Hit by a Nouss & $\begin{array}{l}\text { Corneal perforation of the right eye with } \\
\text { inclusion of foreign bodies, periorbital } \\
\text { haematoma }\end{array}$ & 0 & $\begin{array}{l}\text { Hospital/ } \\
\text { surgery }\end{array}$ \\
\hline 7 & M & 68 & $\begin{array}{l}\text { Hit himself with the Träf } \\
\text { while striking }\end{array}$ & $\begin{array}{l}\text { Fracture of the right cheekbone with contused } \\
\text { laceration, pneumocephalus }\end{array}$ & 1 & $\begin{array}{l}\text { Hospital/ } \\
\text { surgery }\end{array}$ \\
\hline 8 & M & 54 & Hit by a Nouss & Contused laceration of the upper lip & 0 & $\begin{array}{l}\text { Surgery/ } \\
\text { home }\end{array}$ \\
\hline 9 & $M$ & 39 & Hit by a Nouss & Contusion and joint effusion of the right knee & NA & Home \\
\hline 10 & M & 41 & Hit by a Nouss & $\begin{array}{l}\text { Several displaced midfacial fractures, subdural } \\
\text { haematoma, contused laceration above the } \\
\text { right orbita, contusion of the right eye }\end{array}$ & 7 & $\begin{array}{l}\text { ICU/ } \\
\text { surgery }\end{array}$ \\
\hline 11 & M & 31 & Hit by a Nouss & $\begin{array}{l}\text { Comminuted fractures of the midface and the } \\
\text { nasal bone, contused laceration below the left } \\
\text { orbita }\end{array}$ & 3 & $\begin{array}{l}\text { Hospital/ } \\
\text { surgery }\end{array}$ \\
\hline 12 & M & 31 & $\begin{array}{l}\text { Hit by a ricocheted } \\
\text { Nouss }\end{array}$ & $\begin{array}{l}\text { Several comminuted midfacial fractures with } \\
\text { contused laceration below the right orbita }\end{array}$ & 2 & $\begin{array}{l}\text { Hospital/ } \\
\text { surgery }\end{array}$ \\
\hline 13 & M & 33 & Hit by a Nouss & $\begin{array}{l}\text { Several comminuted midfacial fractures, } \\
\text { perforation of the right globe, several periorbital } \\
\text { contused lacerations }\end{array}$ & 2 & $\begin{array}{l}\text { Hospital/ } \\
\text { surgery }\end{array}$ \\
\hline 14 & M & 25 & Hit by a Nouss & $\begin{array}{l}\text { Fracture of the left orbital floor, severe ocular } \\
\text { contusion, contused laceration of both eyelids }\end{array}$ & 1 & $\begin{array}{l}\text { Hospital/ } \\
\text { surgery }\end{array}$ \\
\hline 15 & M & 45 & Hit by a Nouss & $\begin{array}{l}\text { Fracture of the right orbital floor, globe rupture } \\
\text { with inclusion of foreign bodies, several } \\
\text { periorbital contused lacerations }\end{array}$ & 1 & $\begin{array}{l}\text { Hospital/ } \\
\text { surgery }\end{array}$ \\
\hline 16 & M & 25 & Hit by a Nouss & $\begin{array}{l}\text { Fracture of the left orbital floor and maxillary } \\
\text { sinus, cheek and ocular haematoma }\end{array}$ & 2 & $\begin{array}{l}\text { Hospital/ } \\
\text { surgery }\end{array}$ \\
\hline 17 & M & 50 & $\begin{array}{l}\text { Hit by a ricocheted } \\
\text { Nouss }\end{array}$ & $\begin{array}{l}\text { Contusion and abrasion of the left cheek, } \\
\text { haematoma of the lower eyelid }\end{array}$ & 0 & Home \\
\hline 18 & M & 36 & Hit by a Nouss & $\begin{array}{l}\text { Fracture of the left lateral orbital wall and frontal } \\
\text { sinus, contused laceration of the outer corner of } \\
\text { the left eye }\end{array}$ & 2 & $\begin{array}{l}\text { Surgery/ } \\
\text { home }\end{array}$ \\
\hline 19 & M & 53 & $\begin{array}{l}\text { Hit by a splintered part of } \\
\text { the Nouss while striking }\end{array}$ & Contused laceration of the left upper lip & 0 & $\begin{array}{l}\text { Surgery/ } \\
\text { home }\end{array}$ \\
\hline 20 & M & 27 & Direct hit by a Nouss & Contused laceration of the forehead & 0 & $\begin{array}{l}\text { Hospital/ } \\
\text { surgery }\end{array}$ \\
\hline 21 & M & 25 & Hit by a Nouss & Haematoma of the nasal septum & 0 & $\begin{array}{l}\text { Hospital/ } \\
\text { surgery }\end{array}$ \\
\hline 22 & M & 48 & $\begin{array}{l}\text { Blow on the mandible at } \\
\text { Hornussen }\end{array}$ & Fracture of the mandible & 1 & $\begin{array}{l}\text { Hospital/ } \\
\text { surgery }\end{array}$ \\
\hline 23 & M & 40 & Hit by a Nouss & $\begin{array}{l}\text { Contusion and comminuted fracture of the right } \\
\text { middle finger }\end{array}$ & NA & $\begin{array}{l}\text { Surgery/ } \\
\text { home }\end{array}$ \\
\hline 24 & M & 19 & $\begin{array}{l}\text { Hit by a ricocheted } \\
\text { Nouss }\end{array}$ & $\begin{array}{l}\text { Contused laceration of the upper lip, fracture of } \\
\text { the nasal spine }\end{array}$ & 1 & $\begin{array}{l}\text { Surgery/ } \\
\text { home }\end{array}$ \\
\hline
\end{tabular}


Table 2 Continued

\begin{tabular}{|c|c|c|c|c|c|c|}
\hline $\begin{array}{l}\text { Patient } \\
\text { number }\end{array}$ & Gender & Age & Cause of accident & Diagnoses & FISS & Outcome \\
\hline 25 & M & 39 & Hit by a Nouss & $\begin{array}{l}\text { Fracture of the right cheekbone, contused } \\
\text { laceration of the right nasal wing }\end{array}$ & 1 & $\begin{array}{l}\text { Hospital/ } \\
\text { surgery }\end{array}$ \\
\hline 26 & $\mathrm{M}$ & 35 & $\begin{array}{l}\text { Hit by a shattered } \\
\text { Stecken while punting }\end{array}$ & $\begin{array}{l}\text { Fracture of the mandible with contused } \\
\text { laceration }\end{array}$ & 2 & $\begin{array}{l}\text { Hospital/ } \\
\text { surgery }\end{array}$ \\
\hline 27 & M & 29 & Hit by a Nouss & $\begin{array}{l}\text { Fracture of the right cheekbone, orbital floor } \\
\text { and tooth } 18 \text { with contused laceration }\end{array}$ & 3 & $\begin{array}{l}\text { Hospital/ } \\
\text { surgery }\end{array}$ \\
\hline 28 & M & 26 & $\begin{array}{l}\text { Hit by a ricocheted } \\
\text { Nouss }\end{array}$ & $\begin{array}{l}\text { Several midfacial fractures, severe ocular } \\
\text { contusion, contused laceration of the upper lid }\end{array}$ & 4 & $\begin{array}{l}\text { Hospital/ } \\
\text { surgery }\end{array}$ \\
\hline
\end{tabular}

(SD 0.83, maximum 2); in contrast, the median inpatient FISS was 1.9 (SD 1.68, maximum 7).

The most common injuries found were soft tissue lesions (92\%)-predominantly (19 out of 24 cases) contused lacerations-and fractures $(69 \%)$, mainly of the midface and the orbital cavities. Significant ocular trauma (blunt and perforating) was found in $35 \%$ of our patients. There were two patients with tooth damage $(8 \%)$. A total of 54 injuries were recorded in 26 patients (figure 6), most patients suffered combined trauma.

\section{Combined trauma as a rule}

The most frequent combination was fracture and contused laceration, in 15 of 26 patients $(58 \%)$. Seven out of $9(78 \%)$ patients with significant ocular trauma also exhibited at least one fracture and one contused laceration (figure 7). The remaining two patients were affected by an ocular trauma combined with a fracture and a superficial haematoma or by an isolated perforating ocular trauma caused by a shattered eyeglass lens.

There was a clear trend that the outcome of patients depended on the complexity of the injuries. Of the eight patients with a single injury, four could be treated as outpatients and four were admitted to hospital care. Seven of nine patients $(78 \%)$ with two different injuries had to be hospitalised, as were all patients with three different injuries. The only patient with four different injuries was admitted to the ICU. These last two groups had all suffered from severe ocular trauma or subdural haematoma.

Interestingly, there was essentially no difference between the patients hit by a ricocheted Nouss $(n=5)$ and the others $(\mathrm{n}=15,2$ direct hits and 13 cases without detailed information). Apart from the one female patient, who was most probably hit by a Nouss that was already moving slowly, three of the four active players suffered severe midfacial trauma, as well as one with additional severe blunt ocular trauma. The mean FISS

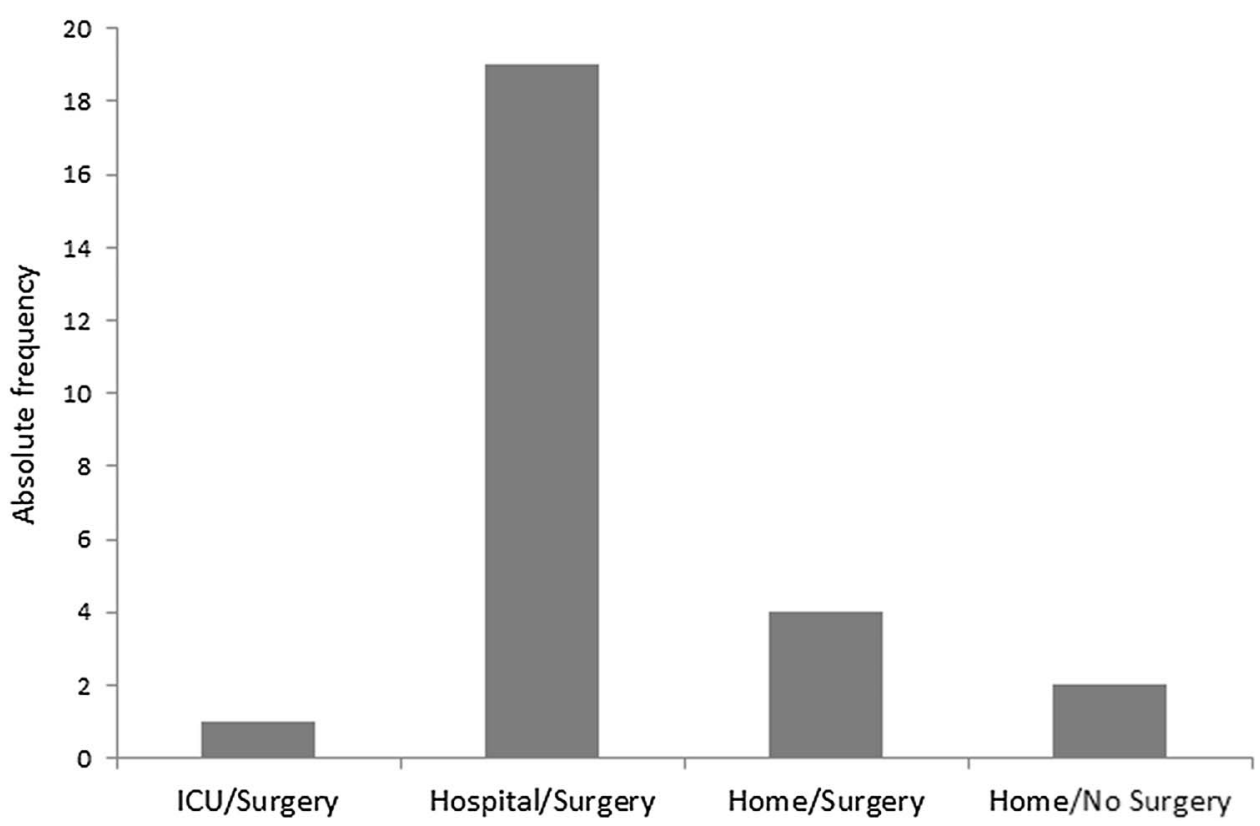

Figure 5 Patient outcome. ICU, intensive care unit. 


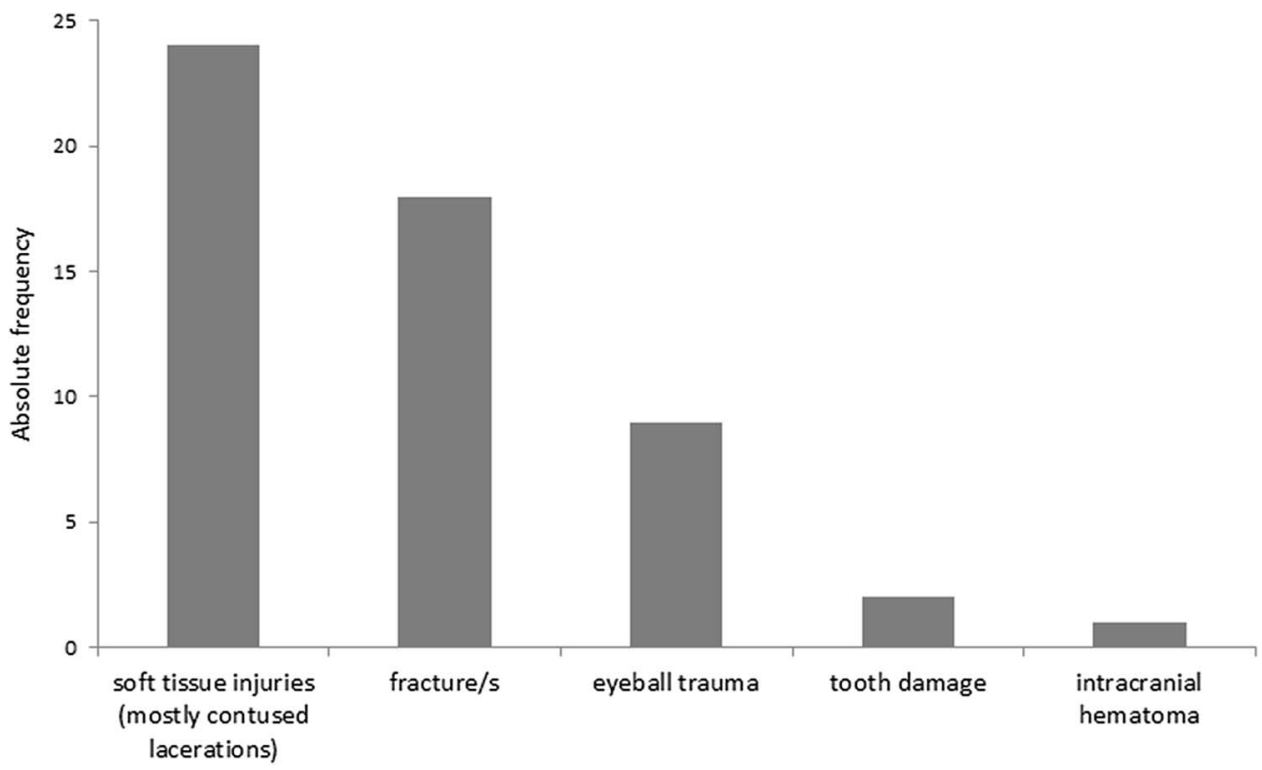

Figure 6 Type of injuries.

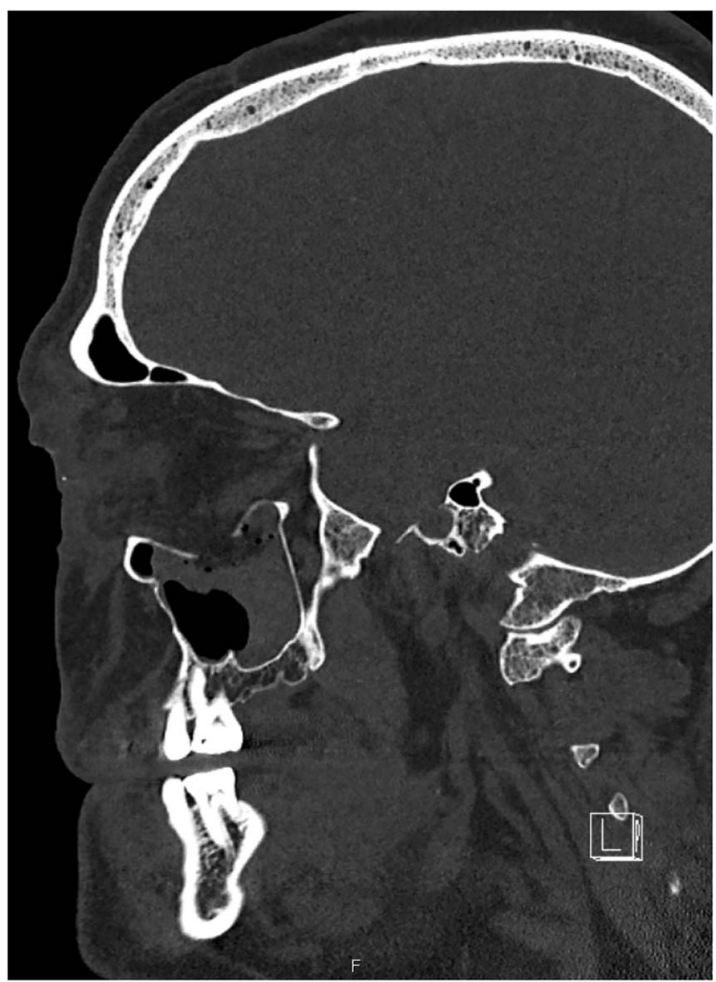

Figure 7 Sagittal CT scan of the midface demonstrating an extended orbital floor fracture caused by a Nouss. This patient also suffered significant ocular trauma.

caused by ricocheted hits was 1.4 vs 1.87 (direct hits or unclear).

\section{DISCUSSION}

The typical patient affected by a Hornussen accident is an active male player with a mean age of about 40 years who did not use protective gear. Although in 1999 the Swiss Hornusser Association made protective helmets with face shield (either cage or polycarbonate visor, similar to ice hockey equipment) mandatory for players born 1984 or after, we found two younger patients (born in 1988 and 1986) with midfacial trauma (FISS 1 in both cases); one of them additionally suffered from a severe blunt ocular trauma. Neither of these patients had used a helmet.

\section{Ophthalmological injuries}

Ocular trauma caused by Hornussen generally tends to be severe. ${ }^{12-16}$ This was confirmed by our nine such patients, whose blunt and perforating/penetrating ocular injuries required surgical intervention in all cases. Typical clinical findings comprised corneal laceration and perforation, iridal trauma and lens dislocation. Unfortunately, our data can give no information about early complications or secondary surgery (eg, enucleation). This is also the case for long-term sequelae, such as glaucoma, impaired visual acuity or even blindness. However, the medical literature provides evidence that significant visual impairment is a regular consequence of Hornussen or other similar sports accidents. Caduff $^{12}$ mentioned six patients with severe ocular damage after Hornussen, which led to the payment of pension funds in four of these cases. Casotti $e t a l^{13}$ described a small series of three Hornussen players with ocular injury after one direct and two ricocheted hits by a Nouss, which caused one perforating and two blunt contusional ocular lesions. The perforation injury led to blindness; moreover two patients suffered orbital roof and floor fractures. Similar cases have been reported in the daily press. ${ }^{14-16}$ Weitgasser $e t a l^{21}$ reviewed seven cases of ocular trauma from golf and mentioned the additional risk of perforated globes from shattered eyeglass lenses. This was precisely the case in two of our patients. Other publications have reported comparable serious eye injuries from other sports or recreational 
activities, such as paintball, ${ }^{22}$ badminton and ice hockey. ${ }^{23}$ Approximately $30-40 \%$ of the cases resulted in permanent and significant visual impairment or even legal blindness. Seventy-two per cent of all sport-related eye injuries may have to be followed up for life, as they are accompanied by an increased risk of glaucoma. ${ }^{23}$ The outcome is even worse for perforating and penetrating eye injuries requiring open globe repair. Depending on trauma severity and infectious complications (endophthalmitis), $\sim 70 \%$ of these patients may suffer blindness and up to $29 \%$ enucleation. ${ }^{24}{ }^{25}$ It is clear that the characteristics of Hornussen-induced eye injuries cannot so easily be compared with those inflicted during other sports, as it must be emphasised that a Nouss significantly exceeds the size of a golf ball, or a shuttlecock in badminton. Thus, these projectiles fit better into the orbital cavity than a Nouss does and more easily cause eye injury. The Nouss, however, consistently leads to fractures of the bony structures of the orbita and other midfacial bones that protect the eye, as it is harder and larger. But after the accident, the severity and outcome of Hornussen eye injuries may not essentially differ from other types of eye injury.

\section{Maxillofacial trauma}

There is much less recent literature on sport-related midfacial/maxillofacial fractures than on sport-related eye injuries. Perhaps the potential loss of a sensory organ encourages more research and publication than reports of 'simple' fractures. Moreover, there are notable cultural influences, as many studies originate from central Europe and deal with the favourite local sports, mainly soccer, which predominantly leads to mandibular fractures. ${ }^{17}{ }^{26}{ }^{27}$ Bat-and-ball sports like baseball or cricket typically cause maxillofacial fractures and are more or less restricted to Anglo-American and Australasian publications. ${ }^{28-33}$ But in general, all authors found that the typical patient affected by such fractures is a male, with a gender ratio mainly around 7:1 to $14: 1$ (maximum 36:1). ${ }^{26-33}$ This fits well to our own patient group and is of course because more or less all of the evaluated sports are mostly performed by male participants. Studies focusing on facial trauma resulting from activities of daily life have found a much more balanced gender ratio of around 2:1. ${ }^{34}$ Papers on cricket or baseball consistently report midfacial/maxillofacial fractures. Injuries to the orbitozygomatic region are most typical, and impact from a ball is the most frequent cause. ${ }^{28-33}$ This is also totally consistent with our present results. On the other hand, the age distribution of our Hornussen sample differs from that in other sports, as soccer, rugby and baseball are predominantly played by participants below 35 years of age, whereas 8 of our 28 patients were aged 50 years or more.

But to what extent do maxillofacial fractures compromise post-traumatic well-being compared with ocular injuries? Transient and persistent post-traumatic damage of the sensory infraorbital nerve was recorded most frequently (up to $66 \%$ ) and is a consequence of orbitozygomatic fractures. ${ }^{36-38}$ Sustained damaged motor function of the facial nerve would definitely have a greater impact on the individual than a damaged pure sensory nerve and was reported with a frequency of $2.3 \% .^{38}$ Functional ophthalmological impairment from persistent diplopia, enophthalmos or limited eye movement was an additional complication in $\sim 15 \%$ of patients. ${ }^{36} 38$ Chronic rhinosinusitis with facial pain and disturbed sleep have also been described after surgical intervention in midfacial fractures. ${ }^{39}$ Could these findings be representative of our study population as well? The median FISS of our 16 patients with midfacial fractures (excluding the two patients with isolated mandibular fracture) was 2.25. The median FISS values of larger groups of patients covered a range from 1.37 to $1.97 .^{37}$ Only patients injured by traffic accidents or falls from heights above $3 \mathrm{~m}$ displaved considerably higher median FISS values of 3.4-6.0. ${ }^{20} 40^{41}$ Thus, we conclude that our Hornussen injury patients reach midfacial trauma levels comparable to those of other populations-except for serious traffic accidents and fallsand may be equally affected by the long-term complications of maxillofacial fractures.

\section{Conclusions and suggestions for prevention}

Most Hornussen accidents do not of course involve severe midfacial or ocular trauma. Fractures of the fingers or contusions/contused lacerations of the trunk or the extremities, as found in two of our patient sample, are certainly much more common Hornussen injuries. ${ }^{15} 16$ These minor injuries are very seldom admitted to a university level I trauma centre but are regularly and adequately treated in smaller communal or regional hospitals of, for example, level III. Consequently our data are affected by a marked selection bias. We made an informal inquiry to the Swiss National Accident Insurance Fund (SUVA, Schweizerische Unfallversicherungsanstalt) and were informed that around 100 Hornussen accidents yearly are reported and dealt with by the leading accident insurer of Switzerland. This would suggest that the frequency of significant maxillofacial or ophthalmological trauma can hardly be higher than $2 \%$ or $3 \%$ of all Hornussen incidents, as we surveyed 26 cases within a time frame of 15 years and our university hospital's catchment area reaches $\sim 80 \%$ of all organised Hornussen players (Eidgenössischer Hornusserverband, personal communication). ${ }^{9}$ But apart from the individual consequences of these rare catastrophic events, which can change a life forever, major trauma entails a high economic burden on the community, through treatment costs and sick leave. It is well documented for other sports that compulsory wearing of protective gear greatly reduces severe head injury. ${ }^{42-45}$ Consistent use of protective helmets with additional face shield should therefore be made mandatory for all age groups of Hornussen players and preferably not be restricted to the intercepting players in the field, as 4 (15\%, median FISS 1) of our 
26 patients were injured while punting the Nouss from the Bock. The existing regulation for players born 1984 or after should accordingly be expanded.

Acknowledgements The authors thank Sebastian Wolf, Department of Ophthalmology, University Hospital Bern, for reviewing this article.

Contributors AE motivated the planning and the conduct of the study. MR provided the clinical database research. VW drafted the manuscript and performed the statistical evaluation. BS helped to transform the clinical data into the Facial Injury Severity Scale (FISS) score values. All authors gave editorial input, read and approved the final revision of the submitted manuscript.

\section{Competing interests None declared.}

Provenance and peer review Not commissioned; externally peer reviewed.

Data sharing statement No additional data are available.

Open Access This is an Open Access article distributed in accordance with the Creative Commons Attribution Non Commercial (CC BY-NC 4.0) license, which permits others to distribute, remix, adapt, build upon this work noncommercially, and license their derivative works on different terms, provided the original work is properly cited and the use is non-commercial. See: http:// creativecommons.org/licenses/by-nc/4.0/

\section{REFERENCES}

1. Eidgenössischer Hornusserverband. Hornusser Hand- und Lehrbuch. Brittnau: EHV, 1985.

2. PDF available from http://www.lebendige-traditionen.ch (accessed 21 Aug 2015).

3. https://www.youtube.com/watch?v=GdIHOV6VGNU (accessed 21 Aug 2015).

4. http://www.ehv.ch/hornussen (accessed 21 Aug 2015)

5. Kneubuehl BP. The Ballistics of "Hornussen". In: Crewther IR, ed. IBS 2001: 19th international Symposium on Ballistics, 7-11 May 2001, Interlaken, Switzerland, Casino Kursaal Congress Center: Proceedings [Vol. 1]. Thun: RUAG Land Systems, 2001:3-8.

6. Rubi C. Vom Hornussen im Emmental und anderwärts. Eds: Staatsarchiv des Kantons Bern, Stadtarchiv Bern, Stadt- und Hochschulbibliothek Bern und Historisches Museum in Bern. In: Berner Zeitschrift für Geschichte und Heimatkunde. Vol 2. Bern: Verlag Paul Haupt, 1940:39-44.

7. Eggimann EW. Hornussen-Vom Spiel zum Sport. Eds: Staatsarchiv des Kantons Bern, Stadtarchiv Bern, Stadt- und Hochschulbibliothek Bern und Historisches Museum in Bern In: Jahrbuch des Oberaargaus. Vol 39. Wangen a. A. I Herzogenbuchsee: Jahrbuch-Vereinigung Oberaargau. 1996:17-30.

8. http://www.ehv.ch (accessed 21 Aug 2015).

9. http://www.blick.ch/news/schweiz/sportanlagen-in-der-schweiz-diewelschen-haben-keine-lust-auf-hornussen-id2433893.html (accessed 21 Aug 2015)

10. http://www.ehv.ch/hornussen/schlagen (accessed 21 Aug 2015)

11. Kneubuehl BP, Coupland RM, Rothschild MA and Thali M. eds. Wundballistik. Heidelberg: Springer, 2008:261-2.

12. Caduff R. Augenverletzungen im Sport. In: Biener K, ed. Grenzbereiche der Sportmedizin. Heidelberg: Springer, 1990:113-36.

13. Casotti ME, Frueh BE, Goldblum D. [Eye injuries caused by "Hornussen"-a traditional Swiss team game]. Klin Monbl Augenheilkd 2003;220:182-5.

14. http://www.solothurnerzeitung.ch/sport/solothurn/erblindeterhornusser-war-mir-nicht-bewusst-dass-es-so-schmerzenueberhaupt-gibt-128040888 (accessed 21 Aug 2015)

15. http://www.solothurnerzeitung.ch/sport/solothurn/wieso-imhornussen-immer-mehr-helme-mit-im-spiel-sind-128151961 (accessed 21 Aug 2015)

16. http://www.watson.ch/Best\%20of\%20watson/Sport/698304704-AlsDeutscher-beim-Hornussen-Wenn-Schweizer-sich-eine-Sportartausdenken-dann-muss-man-schon-mal-den-Kopf-einziehen (accessed 21 Aug 2015)

17. Exadaktylos AK, Eggensperger NM, Eggli S, et al. Sports related maxillofacial injuries: the first maxillofacial trauma database in Switzerland. Br J Sports Med 2004;38:750-3.

18. Bagheri SC, Dierks EJ, Kademani D, et al. Application of a facial injury severity scale in craniomaxillofacial trauma. J Oral Maxillofac Surg 2006;64:408-14.
19. Bagheri SC, ed. Clinical review of oral and maxillofacial surgery. St. Louis: Mosby, 2013:224.

20. Ramalingam S. Role of maxillofacial trauma scoring systems in determining the economic burden to maxillofacial trauma patients in India. J Int Oral Health 2015;7:38-43.

21. Weitgasser U, Wackernagel W, Oetsch K. Visual outcome and ocular survival after sports related ocular trauma in playing golf. J Trauma 2004;56:648-50.

22. Pahk PJ, Adelman RA. Ocular trauma resulting from paintball injury. Graefes Arch Clin Exp Ophthalmol 2009;247:469-75.

23. Leivo T, Haavisto AK, Sahraravand A. Sports-related eye injuries: the current picture. Acta Ophthalmol 2015; 93:224-31.

24. Mackiewicz J, Machowicz-Matejko E, Sałaga-Pylak M, et al. Work-related, penetrating eye injuries in rural environments. Ann Agric Environ Med 2005;12:27-9.

25. Kong GY, Henderson RH, Sandhu SS, et al. Wound-related complications and clinical outcomes following open globe injury repair. Clin Experiment Ophthalmol 2015;43:508-13.

26. Mourouzis C, Koumoura F. Sports-related maxillofacial fractures: a retrospective study of 125 patients. Int J Oral Maxillofac Surg 2005;34:635-8.

27. Maladière E, Bado F, Meningaud JP, et al. Aetiology and incidence of facial fractures sustained during sports: a prospective study of 140 patients. Int J Oral Maxillofac Surg 2001;30:291-5.

28. Delilbasi C, Yamazawa M, Nomura K, et al. Maxillofacial fractures sustained during sports played with a ball. Oral Surg Oral Med Oral Pathol Oral Radiol Endod 2004;97:23-7.

29. Lim LH, Moore MH, Trott JA, et al. Sports-related facial fractures: a review of 137 patients. Aust N Z J Surg 1993;63:784-9.

30. Bak MJ, Doerr TD. Craniomaxillofacial fractures during recreational baseball and softball. J Oral Maxillofac Surg 2004;62:1209-12

31. Antoun JS, Lee KH. Sports-related maxillofacial fractures over an 11-year period. J Oral Maxillofac Surg 2008;66:504-8.

32. Hwang K, You SH, Lee HS. Outcome analysis of sports-related multiple facial fractures. J Craniofac Surg 2009;20:825-9.

33. Lee K. Cricket related maxillofacial fractures. J Maxillofac Oral Surg 2012;11:182-5.

34. Gassner R, Tuli T, Hächl O, et al. Cranio-maxillofacial trauma: a 10 year review of 9,543 cases with 21,067 injuries. J Craniomaxillofac Surg 2003;31:51-61.

35. Zix JA, Schaller B, Lieger O, et al. Incidence, aetiology and pattern of mandibular fractures in central Switzerland. Swiss Med Wkly 2011;141:w13207.

36. Bartoli D, Fadda MT, Battisti A, et al. Retrospective analysis of 301 patients with orbital floor fracture. J Craniomaxillofac Surg 2015;43:244-7

37. Boffano P, Roccia F, Gallesio C, et al. Infraorbital nerve posttraumatic deficit and displaced zygomatic fractures: a double-center study. J Craniofac Surg 2013;24:2044-6.

38. Motamedi MH, Dadgar E, Ebrahimi A, et al. Pattern of maxillofacial fractures: a 5-year analysis of 8,818 patients. J Trauma Acute Care Surg 2014;77:630-4.

39. Yelverton JC, Jackson P, Schmidt RS. Chronic rhinosinusitis in patients requiring surgical repair of a midface fracture. Ear Nose Throat J 2014;93:E26-8.

40. Roccia F, Boffano P, Bianchi FA, et al. Maxillofacial fractures due to falls: does fall modality determine the pattern of injury? J Oral Maxillofac Res 2014;5:e5.

41. Kesuma AD, Bangun K. Evaluation of facial trauma severity in Cipto Mangunkusumo Hospital using FISS scoring system. J Plast Rekonstruksi 2012;1:162-5.

42. Vinger PF. Baseball eye protection: the effect of impact by major league and reduced injury factor baseball on currently available eye protectors. In: Hoerner E, Cosgrove F, eds. International symposium on safety in baseball/softball. Vol ASTM STP 1313. Philadelphia: American Society for Testing and Materials, 1997:29-37.

43. McIntosh AS, Janda D. Evaluation of cricket helmet performance and comparison with baseball and ice hockey helmets. $\mathrm{Br} J$ Sports Med 2003;37:325-30

44. Shaw L, Finch CF. Injuries to junior club cricketers: the effect of helmet regulations. Br J Sports Med 2008;42:437-40.

45. Henke T, Kantner F, Moschny A. Sportunfälle im Profi-Eishockey -Epidemiologie und Prävention [Projektarbeit]. Lehrstuhl für Sportmedizin und Sporternährung: Ruhr-Universität Bochum. 2009. 